\title{
Výzkum v didaktice biologie, geologie a environmentální výchovy v České republice v letech 2008-2018
}

\author{
Review of Biology, Geology and Environmental Education Research in the Czech \\ Republic from 2008 to 2018
}

\author{
Roman Kroufek ${ }^{1, *}$, Martin Jáč ${ }^{2}$, Vanda Janštová ${ }^{3}$, Martina Pražáková ${ }^{4}$, Kateřina Čiháková ${ }^{5}$ \\ ${ }^{1}$ Pedagogická fakulta, Univerzita J. E. Purkyně, Pasteurova 1, 40096 Ústí nad Labem, Česká republika; kroufek@gmail.com \\ 2 Pedagogická fakulta, Univerzita Palackého, Purkrabská 2, 77900 Olomouc, Ceská republika \\ ${ }^{3}$ Př́rodovědecká fakulta, Univerzita Karlova, Viničná 7, 12800 Praha 2, Česká republika \\ ${ }^{4}$ Pedagogická fakulta, Univerzita Karlova, Magdalény Rettigové 4, 11639 Praha 1, Česká republika. \\ ${ }^{5}$ Pedagogická fakulta, Jihočeská univerzita, Jeronýmova 10, 37115 České Budějovice, Česká republika
}

Primárním cílem studie je podat přehled českého výzkumu v didaktice biologie, geologie a environmentální výchovy v období mezi lety 2008-2018. Pro naplnění tohoto cíle byla provedena obsahová analýza 145 textů daného zaměření vydaných v časopisech se standardním recenzním řízením. Nejvíce příspěvků bylo publikováno v časopisech Envigogika a Scientia in educatione, které se přímo soustředí na environmentální výchovu, resp. didaktiku přírodních věd. $\mathrm{V}$ analyzovaných textech převažovaly výzkumy s kvantitativním designem, respondenty byli nejčastěji žáci druhého stupně základních škol. Teoretické studie jsou v českém prostředí zastoupeny málo, stejně jako studie věnované kurikulu. Výzkumné statě byly relativně často věnovány evaluaci, př́padně badatelsky orientované výuce. Dobrou zprávou pro didaktiku biologie a environmentální výchovy je kromě tradice oborových konferencí a existence dvou oborově didakticky zaměřených doktorských studijních programů i to, že zaměřením výzkumů nevybočuje z mezinárodních trendů.

The primary objective of the study is to summarize Biology, Geology \& Environmental Education Research in the Czech Republic from 2008 to 2018. To achieve this goal, a content analysis of 145 texts of the given topic published in journals with standard review procedures was performed. Most contributions were published in the journals Envigogika and Scientia in educatione, which focus directly on environmental education and science education, respectively. In the analyzed texts, research with quantitative design prevailed and the respondents were mostly lower-secondary school pupils. Theoretical studies are underrepresented in the Czech environment, as well as studies on the curriculum. Research articles were relatively often devoted to evaluation or inquiry-based science education. The good news for the Biology \& Geology and Environmental Education Research community is, besides the tradition of professional conferences and the existence of two doctoral degree programs, the fact that the focus of research does not substantially differ from international trends.
Klíčová slova: didaktika biologie, didaktika geologie, environmentální výchova, výzkumné trendy, obsahová analýza.

Zasláno 2/2019

Revidováno 3/2020

Prijato 4/2020

\section{1 Úvod}

Výzkumné trendy jsou v jednotlivých oborech dlouhodobě sledovány a nejinak je tomu také v př́ípadě výzkumu přírodovědného vzdělávání. Abychom měli jasnější představu o situaci v České republice, přináší předložená studie přehled a zhodnocení výzkumných prací, které byly v didaktice biologie, geologie a environmentální výchovy zveřejněny v období 2008-2018. Kromě kvantitativní analýzy publikovaných textů byl sledován také vývoj diskurzu uvedených vědních disciplín, jeho silných a slabých stránek. Souběžným cílem bylo identifikování textů, které mají potenciál ovlivnit revize stěžejního kurikulárního dokumentu České republiky. ${ }^{1}$

Z dlouhodobého hlediska je potřebné, aby měl výzkum zaměřený na vzdělávání široký záběr, což platí i pro zkoumání vzdělávání v přírodních vědách, jak argumentují Gilbert et al. (2003) na příkladu chemie. Pokud takový výzkum pokrývá širokou paletu témat a přístupů, spíše poskytne komplexní obraz reality. Studie systematicky mapující trendy ve výzkumu zaměřeném na vzdělávání v přírodních vědách (science education) ukazují, že v průběhu let se mění zastoupení zkoumaných témat i použitých metod (Lee et al., 2009; Chang et al., 2010; Lin et al., 2014; Lin et al., 2018).

Výsledky těchto analýz jsou důležité při orientaci v oboru (nejen) pro začínající výzkumníky, ale i pro vyučující z praxe. Napomáhají také identifikaci tematických mezer v zaměření realizovaných vý-

\footnotetext{
${ }^{1}$ Text původně vznikl jako kapitola podkladové studie připravené širším týmem pro revize Rámcových vzdělávacích programů v oblasti př́rodopisu, biologie a geologie (Rokos \& Holec, Eds., 2019, s. 32-41). Předkládáme jej upravený a rozšířený.
} 
zkumů, které pak mohou být vyplněny, at už přímo novým bádáním, nebo vypsáním vhodně zaměřených výzkumných výzev (Lin et al., 2018). Nejdéle jsou v tomto směru sledovány jádrové časopisy považované za vůdčí v oboru didaktiky přírodovědných předmětů (např. International Journal of Science Education, Journal of Research in Science Teaching, Research in Science Education, Research in Science 8 Technological Education, Journal of Biology Education či Science Education). Systematické sledování publikovaných studií začalo $\mathrm{v}$ roce 1998. V prvních pěti letech (1998-2002) mezi tématy převažovalo studentské pojetí učení, výzkumy se věnovaly také kurikulu a vzdělávací politice (Tsai \& Wen, 2005). Lee et al. 2009, kteří mimo jiné sledovali i zemi původu autorů analyzovaných publikací, poukázali na nárůst zastoupení autorů z neanglicky mluvících zemí v průběhu let 2003-2007. Autoři se na rozdíl od předchozího sledovaného období také více zaměrili na kontext žákovského učení. Toto téma velmi rezonovalo mezi výzkumníky i v následujícím období (2008-2012), ve kterém byly nejvíce citovány práce týkající se dále např. badatelsky orientované výuky a použití a pochopení modelů a př́měrů v přírodních vědách (Lin et al., 2014). Zatím poslední srovnání z let 2013 až 2017 ukázalo, že mezi nejvíce zastoupené patřil výzkum žákovských pojetí a představ (prekoncepcí), zejména o stěžejních a zastřešujících tématech př́rodních věd, jako je např́íklad energie (Lin et al., 2018). Autoři také poukazují na trendy jasné po celé dvě sledované dekády. Např́ílad téma pojetí výuky, které bylo na začátku sledovaného období hojně zastoupené, je od roku 2003 na ústupu, zatímco pokles počtu příspěvků věnovaných kurikulu a vzdělávací politice byl zastaven. Podrobnější pohled na 10 nejcitovanějších prací ukázal, že mezi výzkumníky v posledních letech nejvíce rezonovala nerovnost $\mathrm{v}$ přírodovědném a technickém vzdělávání (STEM; Science, Technology, Engineering, and Mathematics) a zkoumání zkušeností studentů s výzkumem (Lin et al., 2018). Podle autorů Chang, Chang a Tseng (2010) byly mezi lety 1990 až 2007 nejvíce používané myšlenkové rámce konstruktivismu či kognitivní psychologie.

Dirks (2011) zpracovala přehledovou studii zaměřenou na výzkum v didaktice biologie (Biology Education Research) v letech 1990 až 2010, přičemž analyzovány byly pouze výzkumné publikace na úrovni terciárního vzdělávání (undergraduate level). Ve zmiňovaném období bylo publikováno celkem 195 studií, přičemž většinu z nich $(86 \%)$ tvořily odborné články publikované v recenzovaných časopisech $(62$ různých časopisů). Nejvíce studií bylo publikováno v pouhých 4 časopisech: Cell Biology Education/CBE-Life Sciences Education, Journal of Research in Science Teaching, Advances in Physiology Education a Journal of College Science Teaching, přičemž v mnoha z analyzovaných časopisů byla během dvou sledovaných dekád publikována pouze jedna výzkumná studie z oblasti didaktiky biologie na úrovni terciárního vzdělávání (Dirks, 2011, s. 29-30; srov. Singer et al., 2013, s. 131). Z výsledků vyplynul také výrazný vzestupný trend publikovaných výsledků z oblasti didaktiky biologie, nebot většina článků (83 \%) pocházela z období 2001-2010. Z obsahového hlediska autorka články kategorizovala do tř́ skupin: (a) studentské učení a jeho výsledky, (b) studentské postoje a přesvědčení, (c) konceptové inventáře a další standardizované nástroje (Dirks, 2011).

Další přehledová studie byla zaměřena na výzkum v didaktice biologie publikovaný ve vybraných mezinárodních časopisech v letech 1997 až 2014 (Gül \& Sözbilir, 2016). Autoři analyzovali téměř 1400 článků z oblasti didaktiky biologie, přičemž výzkum nebyl metodicky limitovaný stupněm vzdělávání jako v případě předchozí studie (srov. Dirks, 2011). Nejvíce publikací vyšlo v časopisech Journal of Biology Education (31,3\%) a International Journal of Science Education (24 \%), přibližně $10 \%$ článků bylo publikováno v časopisech Journal of Research in Science Teaching, Science Education a Journal of Science Education and Technology. Z biologických disciplín se výzkumníci nejčastěji zaměřili na problematiku výuky ekologie a životního prostředí (21,7\% realizovaných výzkumů) či genetiku a biotechnologie $(16,5 \%)$. Četné byly také výzkumy zaměřené na problematiku výuky evoluční biologie, naopak výzkumy týkající se výuky botaniky (3\%) byly zastoupeny minimálně. Nejčastěji byly zkoumány výuka a učení spolu s žákovskými postoji k výuce biologie. Hlavní skupiny respondentů představovali žáci druhého stupně základních škol (33,6 \%), studenti vysokých škol $(22,7 \%)$, žáci prvního stupně základních škol $(20,1 \%)$ a učitelé bez ohledu na stupeň školy, na kterém působili (17,7\%). Okrajová pozornost byla věnována výzkumu výuky u studentů doktorských studijních programů, předškolnímu stupni vzdělávání či vztahu rodičů ke školnímu biologickému vzdělávání. Počty respondentů v analyzovaných výzkumných studiích čítaly př̌evážně desítky až nízké stovky respondentů, více než 300 respondentů bylo zahrnuto pouze v 16 procentech výzkumných studií. V analyzovaných výzkumech byl zastoupen kvalitativní (53\%) či kvantitativní (43\%) design, smíšený výzkumný design, který umožňuje komplexnějš́ náhled na zkoumanou problematiku, byl využit pouze ve $4,2 \%$ studií. Data byla nejčastěji sbírána jednorázově pomocí dotazníků, rozhovorů či studiem dokumentů. Výsledky byly nejčastěji prezentovány jako tabulky četností, často byly používány i běžné deskriptivní statistiky a základní statistické testy jako Studentův t-test nebo ANOVA/ANCOVA (Gül \& Sözbilir, 2016). Gül a Sözbilir (2015) nenalezli zásadní rozdíly mezi zaměřením mezinárodních trendů v didaktice biologie a trendů $\mathrm{v}$ didaktice biologie $\mathrm{v}$ tureckém prostředí, kdy zkoumali publikace tureckých autorů jak v mezinárodních tak národních periodikách. 
King (2008) ve své přehledové studii o vzdělávání v geologii (resp. geovědách) upozorňuje na specifika, současné trendy a problémy ve výuce geologie. Jako zásadní problémy označuje nedostatečnou pozornost, která je celosvětově věnovaná výuce geologie a její okrajové postavení na úrovni národního kurikula v jednotlivých státech (srov. též King, 2015, s. 420-423). Z hlediska výsledků výzkumu didaktiky geologie jsou ve studii přehledně shrnuty poznatky o miskoncepcích ve vybraných oblastech geologického učiva (King, 2008, s. 204-209). Lewis a Baker (2010) upozorňují, že ve Spojených státech je poměrně malý zájem o geologii mezi žáky sekundárního a studenty terciárního stupně vzdělávání a nedostatek kvalifikovaných učitelů geologie. Na základě analýzy vybraných problémů v oblasti geologického vzdělávání uvádí, že pro zlepšení současného stavu je nezbytné zaměřit se v didaktice geologie na komplexní výzkum, který bude využivat široké spektrum výzkumných metod a smiśšený výzkumný design, zaměřit se na nové výzkumné směry (např. problematiku zájmu o učitelství geologie) či využívat akční výzkum (Lewis \& Baker, 2010, s. 127-128). Na obdobné problémy s výukou geologie na Slovensku upozorňují Turanová a Ružek (2015). Autoři zmiňují zejména okrajové postavení geologie v kurikulu a výraznou redukci geologického učiva na základních školách a gymnáziích v posledních letech. Zároveň podotýkají, že rozvoj didaktiky geologie jako oboru je úzce provázaný se školní výukou geologie a současné negativní změny ve výuce geologie se mohou projevit stagnací didaktiky geologie a př́pravy učitelů geologie na vysokých školách (Turanová \& Ružek, 2015, s. 128-130).

V českém prostředí se situací ve výzkumech realizovaných v didaktice biologie věnoval v sérii přednášek Papáček (2012, 2016). Souhrnný přehled vývoje oborové didaktiky biologie a spř́ízněných disciplín pak přinesli Papáček et al. (2015) kapitolou Didaktika biologie: didaktika v rekonstrukci v rámci monografie Oborové didaktiky: vývoj - stav - perspektivy (Stuchlíková \& Janík et al., 2015). Už název kapitoly ukazuje, že autoři kriticky zhodnotili jak historii, tak zejména současný stav didaktiky biologie. Období po roce 1989 autoři otvírají popisem jisté stagnace až regrese oboru v průběhu 90. let, která skončila na přelomu tisíciletí. Upozorňují na problém ,generačního hiátu habilitovaných nositelů oboru“ (s. 231, s. 253), ale pozitivně uzavírají tím, že se nacházíme v období, pro které je charakteristická celá řada nadějných změn, jako např. akreditace doktorského studijního oboru Vzdělávání v biologii a etablování oborového časopisu Scientia in educatione. Za nejčastěji řešená témata jimi sledovaného období uvádějí Papáček et al. (2015, s. 248-250) výzkumy zaměřené na znalosti, pochopení učiva a miskoncepce, výzkumy orientované na procesní stránku výuky a výzkumy týkající se kurikula a hodnocení učebnic.

V tomto textu si klademe za cíl na Papáčka et al. (2015) navázat a doplnit jimi popsaný přehled výzkumu v didaktice biologie o aktuální stav.

\section{Výzkumná otázka:}

Jaký je stav českého výzkumu v didaktice biologie, geologie a environmentální výchovy v období 2008-2018 a jaké směry v něm můžeme pozorovat?

\section{Metodologie}

Následující metodologický přehled se týká analýzy článků publikovaných v období 2008-2018 v recenzovaných časopisech (viz kapitola 3.1). Konferenční př́spěvky a vědecké monografie nebyly kvantitativně analyzovány a v přehledu výsledků je $\mathrm{v}$ příslušných kapitolách uveden pouze jejich komentár.

Sběr dat pro analýzu článků proběhl čtyřstupňově, a to následujícím způsobem: 1) pomocí databáze RIV za pomoci klíčových slov (science education, biology education, environmental education, geology education, inquiry based education, IBSE, ...);2) systematickou rešerší dosud vyšlých čísel českých i zahraničních jádrových časopisů; 3) systematickou rešerší z dosud vyšlých čísel českých (obecně) pedagogických časopisů a 4) doplněním článků autory studie, které nebyly zachyceny v krocích 1 až 3 , na základě znalosti konkrétních textů z důvodu neexistence souhrnného indexu českých pedagogických a oborově didaktických časopisů s možností vyhledávání.

Výběr článků pro vlastní analýzu respektoval postupy popsané v The PRISMA statement (Moher et al., 2009), vlastní postup výběru ilustruje obr. 1.

Po vyřazení duplicitních publikací nalezených $\mathrm{v}$ databázi RIV a dalších uvedených zdrojích bylo prostudováno celkem 182 článků. Po studiu abstraktu bylo z počátečního souboru vyřazeno 22 článků, po studiu plného textu bylo vyřazeno dalších 15 článků. Vyřazeny byly články, které neměly charakter výzkumného sdělení či jejichž respondenti nepocházeli z České republiky. Hodnoceny tedy byly všechny články, které seznamovaly s výsledky výzkumů realizovaných v prostředí českého školství, a to včetně textů přehledových. Výsledných 145 článků (viz Příloha 1) bylo podrobeno kvantitativní analýze, při které byly v souladu se zahraničnímu studiemi (Lee et al., 2009; Gül \& Sözbilir, 2015; Gül \& Sözbilir, 2016) sledovány následující ukazatele: rok publikování, časopis, typ článku, zaměření textu, cílová skupina, výzkumný design. 


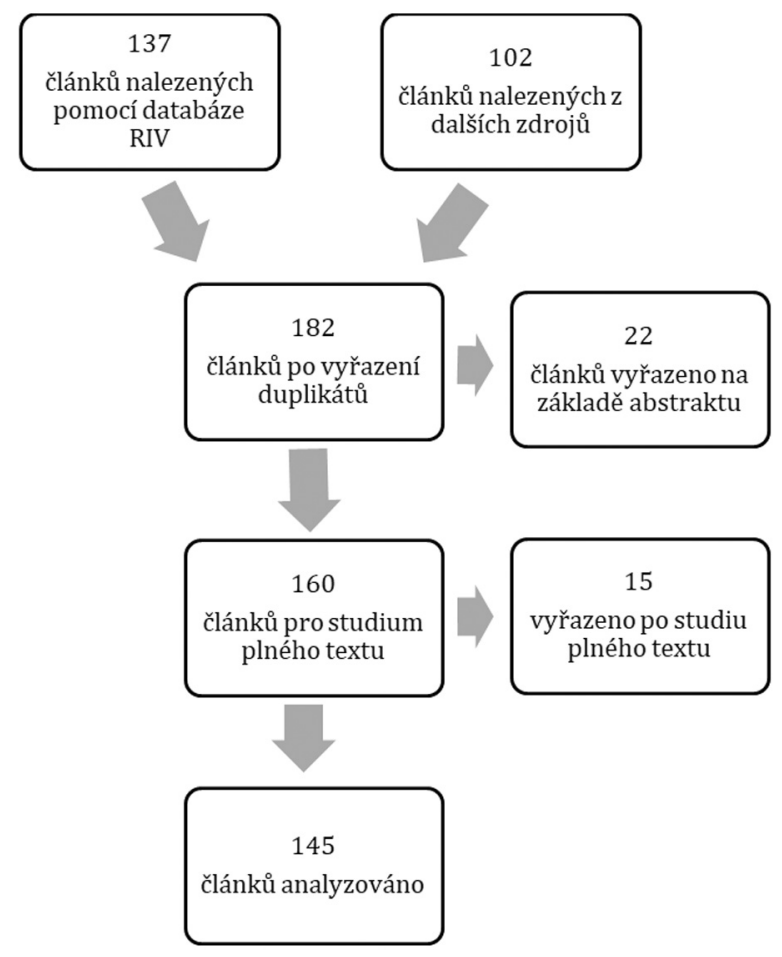

Obr. 1: PRISMA flow diagram pro výběr analyzovaných článků

\section{Výsledky}

Text výsledků je explicitně rozlišen na pojednání o a) časopisech a výstupech v nich uveřejněných analyzovaných dle výše popsané metodologie; b) oborových konferencích; c) stěžejních monografiích a dalších knižních publikacích. K tomuto rozdělení vedla různá kvalita příspěvků vycházející z různé náročnosti, až absence, recenzního řízení. Příspěvky ve sbornících z významnějších konferencí sice procházejí recenzním řízením, ale to má často spíše korektivní charakter. Zatímco u časopiseckých textů je ambicí této studie pokrýt drtivou většinu publikovaných článků obsahujících výzkum v didaktice biologie a geologie, u konferenčních příspěvků je dosažení takového stavu takřka nereálné. Souvisí to jednak s tříštěním výstupů do celé řady konferencí nejrůznější kvality, jednak se stále klesajícím množstvím reálně publikovaných konferenčních sborníků. Současná situace je nakloněna spíše publikování komplexnějších textů v časopisech, což lze považovat za pozitivní trend. V př́padech, kdy z konference není vydán ani sborník abstraktů, není možné z názvů př́spěvků odhadovat jejich charakter a podrobit je analýze. Níže popsaná kvantitativní analýza, tak byla provedena pouze u souboru 145 článků z recenzovaných časopisů (viz kapitola 2).

\section{1 Časopisy publikující výsledky tuzemského výzkumu v didaktice biologie, geologie a environmentální výchově}

Analyzované články byly publikovány v celkem 30 časopisech domácí i zahraniční provenience. V obr. 2 jsou uvedeny ty časopisy, ve kterých byl publikován více než jeden článek. Na prvním místě stojí ryze oborově didaktické časopisy věnované environmentální výchově, respektive didaktice prŕírodních věd, významné množství článků pak bylo publikováno v obecně pedagogických časopisech, a to těch, které jsou více nakloněné oborovým didaktikám. Čtyři a méně publikací na časopis představují jednak výskyty v časopisech, jejichž zaměření není pro výzkum v didaktice biologie a spřízněných oborů zásadní, jednak $\mathrm{v}$ prestižních zahraničních oborových časopisech.

Vědní obory a jejich komunity mají ve zvyku se formovat kolem jádrových časopisů, které v pravidelných intervalech přinášejí nové podněty čtenářum z řad odborné veřejnosti. Jinak tomu není ani v didaktice biologie, kdy roli hlavního takového časopisu vydávaného v Česku zaujímá Scientia in educatione (ISSN 1804-7106), původně vydávaný Pedagogickou fakultou Univerzity Karlovy a v současné době nakladatelstvím Karolinum. V období 2010-2018 v něm bylo publikováno 27 recenzovaných textů zaměřených na nejrůznější oblasti výzkumu v didaktice biologie, geologie a environmentální výchovy. Kromě těchto textů Scientia in educatione pokrývá také potřeby didaktiky matematiky, chemie a fyziky, a stává se tak postupně významnou publikační platformou v přírodovědném vzdělávání u nás. Do jisté míry tak ovlivňuje další směřování tuzemského výzkumu v didaktice biologie. Časopis je aktuálně inde- 
Applied Env. Education \& Comm. 3

Uั

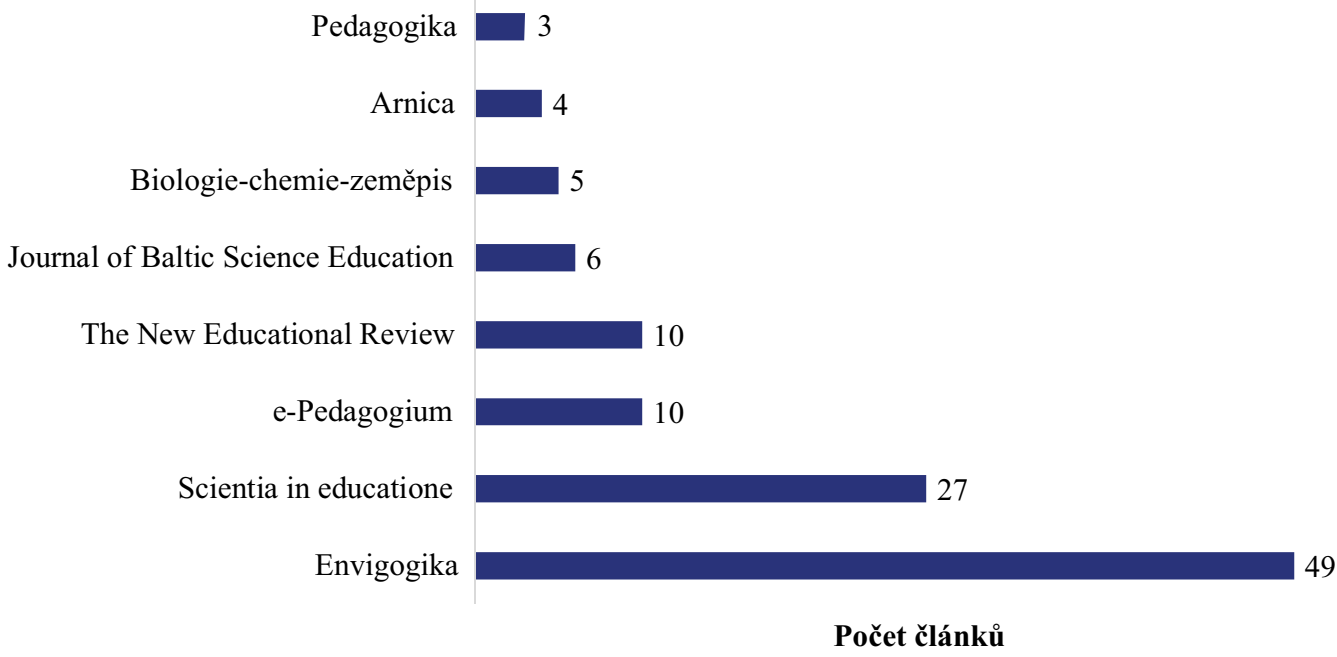

Obr. 2: Počet článků publikovaných ve sledovaném období v jednotlivých časopisech

xován databází ERIH PLUS s výhledem na potřebný vstup do databáze SCOPUS. Předností časopisu je především podrobné recenzní řízení.

Obdobnou roli zaujímá v oblasti environmentální výchovy a vzdělávání časopis Envigogika (ISSN 1802-3061), který vychází od roku 2006 pod patronátem Centra pro otázky životního prostředí Univerzity Karlovy v Praze. Ve sledovaném období zde bylo publikováno množství recenzovaných textů, které pokrývají pestré spektrum témat, od filozofických aspektů environmentalistiky po čistě didaktické př́spěvky. Do sledovaného didaktického výzkumu jich spadá 49 , přičemž někdy je, vzhledem $\mathrm{k}$ prưřezovosti environmentální výchovy, poměrně obtížné stanovit hranice zaměření textu. Podobně jako předchozí časopis, i Envigogika je evidována v databázi ERIH PLUS a také publikuje texty i v anglickém jazyce, od roku 2013 ve formě občasných anglických čísel.

Arnica (ISSN 1804-8366), vydávaná Pedagogickou fakultou Západočeské univerzity, je dalším z časopisů věnovaných primárně didaktice biologie a př́buzných disciplín. Vychází od roku 2011, obsahem je směs výzkumných a metodických článků. V tomto období byla publikována celá řada textů ryze metodického charakteru, které přinášejí pedagogům z praxe doporučení a návody, jak přistupovat ke konkrétním tématům, př́padně představují nestandardní metody výuky konkrétních témat, ale neověřují efektivitu takto prezentovaných metodických př́stupů, a tedy zcela postrádají výzkumný charakter. Určitá obroda nastala v roce 2018, a to pod vlivem projektu Didaktika - Člověk a př́roda A, v rámci kterého bylo připraveno číslo věnované tzv. kritickým místům kurikula.

Nejdelší tradici z časopisů věnovaných didaktice př́rodních věd má u nás Biologie - Chemie - Zeměpis (ISSN 1210-3349), vydávaný od roku 1991, nyní Pedagogickou fakultou Univerzity Karlovy (PedF UK). Spektrum textů je velice pestré, zahrnuje úvahy, vzpomínky a samozřejmě čistě metodické články. Součástí jsou také články výzkumného charakteru, kterých bylo ve sledovaném období publikováno pět.

\subsubsection{Rok publikace časopiseckých článků}

Množství publikovaných článků v jednotlivých letech poměrně kolísá, nicméně určitý vzestupný trend je evidentně patrný (viz obr. 3). Zajímavým jevem je střídání „,silnějších“ a „slabších“ let, které koresponduje s konáním konference Trendy v didaktice biologie. V konferenčních letech $(2014,2016,2018)$ je publikací méně, naopak v letech po konání konference je jich více. 


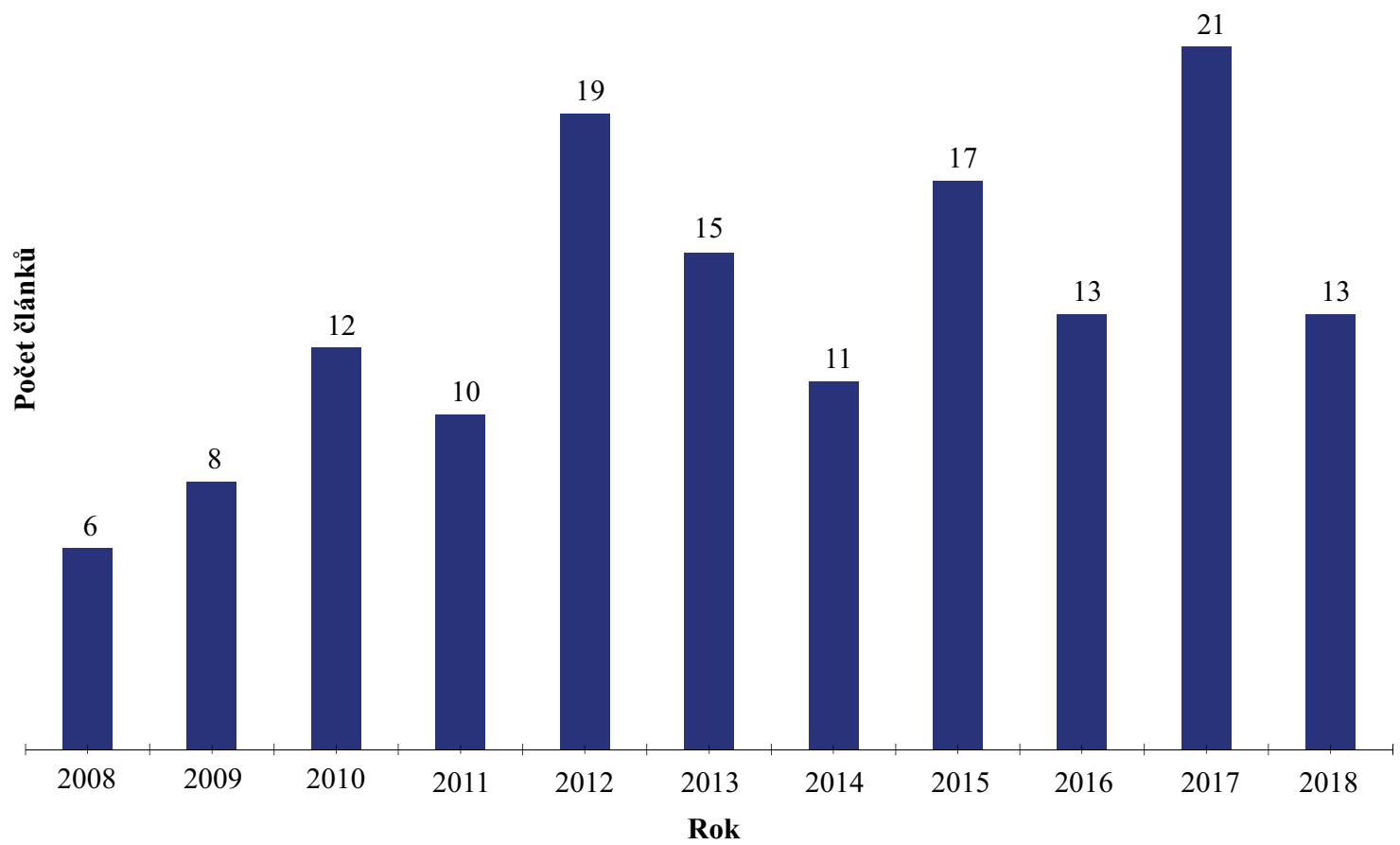

Obr. 3: Počet článků publikovaných v jednotlivých letech sledovaného období

\subsubsection{Typ výzkumného designu}

Šest analyzovaných článků mělo ryze přehledový charakter s jasně definovanou metodikou, 139 textů bylo výzkumných. Snad i kvůli přírodovědnému zázemí většiny výzkumníků v didaktice biologie převažují významně výzkumy s kvantitativním designem (89 textů). Výzkumy ryze kvalitativní (36 textů), př́padně výzkumy se smíšeným designem (14 textů) jsou o poznání vzácnější.

\subsubsection{Tematické zaměření výzkumných studií}

Tematické zaměření jednotlivých textů není proměnná, kterou by bylo možné kategorizovat jednoduchým způsobem. Překryvy, které většina článků představuje, jsou logickým důsledkem charakteru vědeckého textu. Články jednak mohou mít zaměření v rámci biologie jako vědy (např. evoluce, genetika, botanika ,...), jednak z hlediska didaktiky (např. evaluační studie, zjištování postojů k předmětům, analýzy učebnic, ... . . Z těchto důvodů nebyla provedena detailní kvantitativní analýza jednotlivých témat, ale spíše vyzdvihnuta ta, která v textech rezonovala častěji.

Významným výzkumným přístupem jsou evaluační studie (26 článků), které jednak mají v českém prostředí tradici v environmentální výchově a dále jsou do této oblasti zařazeny články věnované konkrétním didaktickým přístupům, obsahují-li řádné zhodnocení jeho dopadi̊. Téma badatelsky orientované výuky rezonuje českým výzkumem prakticky celou dekádu, ve sledovaném období k němu můžeme přiřadit devět textů. Deset textů se pak věnuje kvantitativnímu zjištování postojů žáků a studentů k přírodním vědám, jejich jednotlivým oborům nebo přímo vyučovacím předmětům.

Při oborovém pohledu lze nejvíce článků, celých 24, přiřadit k ekologii a jejím subdisciplínám. To souvisí také s vyšším zastoupením ekologických témat v environmentálně zaměřených textech. Významně méně se pak výzkumem prolínají další oblasti jako zoologie (7 textů), evoluční biologie (6), geologie (3) či botanika (3).

\subsubsection{Cílová skupina realizovaných výzkumů dle stupně vzdělávání}

U těch článků, kde to bylo možné vzhledem k jejich charakteru postihnout (124 textů), byla sledována cílová skupina, tedy stupeň vzdělávání, na který byl výzkum zaměřen. Pohled na zastoupení jednotlivých stupňů podává obr. 4. Pokud se výzkum věnoval více kategoriím respondentů, je uveden u každé z těchto kategorií. Celkový počet textů zobrazených na obr. 4 je tak vyšší, než počet analyzovaných článků. 


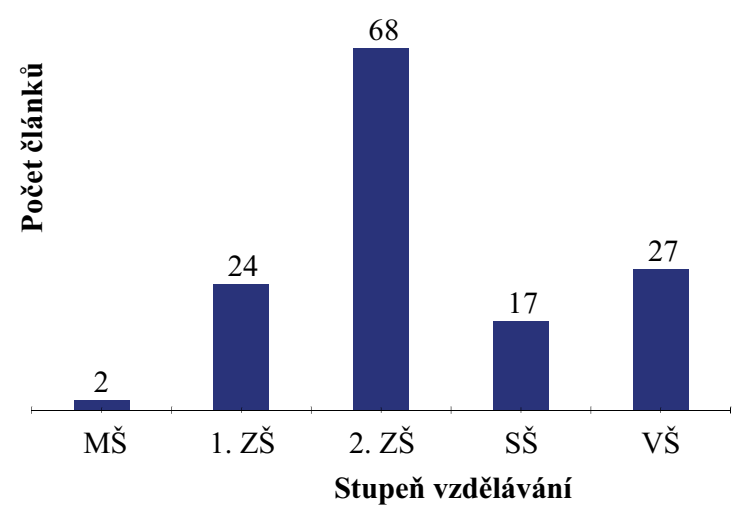

Obr. 4: Zaměření článků dle cílové skupiny vyjádřené stupněm vzdělávání

\subsection{Konference}

Podobně jako jádrové časopisy formují výzkumný diskurz oboru, pomáhají stejně koncipované konference budovat sítě výzkumníků a jsou nezbytným sociálním aspektem, díky kterému se rodí nové způsoby spolupráce. Významnou celostátní konferencí, proběhnuvší ve sledovaném období, která představovala důležitý impulz pro výzkum v didaktice biologie a př́buzných oborech, byl v roce 2010 seminář nazvaný Didaktika biologie v České republice 2010 a badatelsky orientované vyučování. Proběhl na Pedagogické fakultě Jihočeské univerzity v Českých Budějovicích, kde se v té době kolem prof. Papáčka formovala silná skupina zaměřená na problematiku badatelsky orientované výuky.

Na výše zmíněný seminář navázaly konference pořádané na Pedagogické fakultě Univerzity Karlovy pod názvem Trendy $v$ didaktice biologie. S dvouletou periodicitou představují stěžejní událost, na které se setkávají výzkumníci v didaktice biologie, geologie a environmentální výchovy z Ceské republiky i Slovenska. Z konference jsou publikovány pouze sborníky abstraktů. Vlastní př́spěvky jsou někdy následně rozpracovány $\mathrm{v}$ plnohodnotné texty $\mathrm{v}$ recenzovaných časopisech.

Dlouhou tradici mají konferenční setkání zaměřené na Projektové vyučování a dalši aktivizační strategie ve výuce př́rodovědných oborů. Konferenční tradice vznikla v roce 2001 jako primárně studentská setkávání, po roce 2010 se pak konference otevřela dalším účastníkům, a to jak domácím, tak zahraničním (Rusek \& Vojír̆, 2018). Postupně se měnila také šíře jejího záběru, až do současného pojetí otevřeného prakticky všem didaktikům prrírodních věd. Aktuálně se jedná o jedinou českou konferenci zaměřenou i na didaktiku biologie, která je pravidelně indexovaná databází Web of Science.

Specifickou roli v rámci oborově laděných konferencí zaujímá mezinárodní vědecká konference $E D U C O$, v roce 2019 se jedná o XIV. ročník. Konference se současně koná v Tatranské Štrbě na Slovensku a je pořádána ve spolupráci různých vysokoškolských ústavů několika univerzit Ceské a Slovenské republiky. Aktivními členy zde jsou např́íklad Institut vzdělávání a poradenství České Zemědělské Univerzity, Ústav geologie a paleontologie Přírodovědecké fakulty Univerzity Karlovy a další. Jejím cílem je výměna zkušeností a navázání vzájemné spolupráce mezi výzkumníky z různého prostředí.

Geologická tematika ve vzdělávání je také diskutována na Konferenci národních geoparkư, která existuje od roku 2013. Konference je putovní a každým rokem probíhá pod záštitou jiného geoparku.

Naopak v oblasti environmentální výchovy se tradice pravidelných setkávání, na kterých by se prezentovaly výsledky oborového výzkumu, teprve rodí. A to jak ve formě Národni konference $E V V O$, jejižz druhý ročník proběhl v roce 2018, tak více výzkumně zaměřené konference Role univerzit pro rozvoj environmentální výchovy a výchovy pro udržitelný rozvoj. Ta se v roce 2018 dočkala svého druhého ročníku. Je vhodné připomenout, že zatímco výzkumně zaměřené konference environmentální výchovy jsou novinkou, setkání s primárně didaktickou náplní mají v tomto oboru dlouhou tradici. A to jak v podobě pravidelných krajských konferencích EVVO, tak rozsáhlejších akcí jako je Konference k environmentální výchově - Konev, pořádaná od roku 1999 či Národní konference EVVO a environmentálního poradenství, která se ve svém druhém ročníku v roce 2018 otevřela také výzkumným tématům.

\subsection{Monografie a další knižní publikace}

Zajímavou, ale z hlediska výzkumu nedůležitou, oblast představují publikace zaměřené na seznámení se specifickými didaktickými př́stupy. Ve sledovaném období jde např́klad o Př́rodovědné exkurze ve školní praxi (Pavlasová et al., 2015), Činnosti se zvíraty v předškolním vzdělávání (Jančaříková \& Havlová, 2014) či Možnosti využití úloh z Biologické olympiády ve výuce přírodopisu a biologie (Petr, 2014). Významným čistě didaktickým dílem zaměřeným na preprimární a primární edukaci je pak kniha Didaktické př́stupy k př́rodovědnému vzděláváni předškolních dětí a mladšich žákio (Jančaříková, 2015). 
Ryze výzkumná monografie byla ve sledovaném období publikována pravděpodobně pouze jedna. Šlo o výsledky výzkumu podpořeného Grantovou agenturou České republiky. Řezníčková et al. (2013) se zaměřili na biologii, geografii a chemii a zkoumali dovednosti žáků na konci základní školy a na konci čtyřletých i víceletých gymnázií. Kromě této kvantitativní části byly vedeny rozhovory s vyučujícími.

V oblasti environmentální výchovy je situace poněkud optimističtější, byt významně opřená o osobnost Jana Činčery, který stojí za všemi publikovanými monografiemi ve sledovaném období. Mezi nejvýznamnější patří prezentace výsledků výzkumu provedeného na reprezentativním počtu českých pedagogů Environmentální výchova $z$ pohledu učitelů (Činčera et al., 2016), dále analýza role nezávislých environmentálních center (Činčera, 2013a) a komplexní práce Environmentální výchova: efektivní strategie (Činčera, 2013b).

Důležitou přehledovou publikací, která reflektuje stoupající zájem o venkovní učení, a činí tak na podkladě velkého množství výzkumných publikací, je kniha Tajemstvi školy za školou (Daniš, 2018), které otevírá cestu $\mathrm{k}$ učitelům také čtivý jazyk a zdařilé grafické zpracování.

\section{Diskuze}

Výzkum na poli didaktiky biologie v Ceské republice považujeme za etablovaný, s pestrým zastoupením témat, reflektujících řadu „,̌hhavých“ otázek současné didaktiky. Další posilování významu národního výzkumu v této oblasti vidíme $\mathrm{v}$ překročení národních hranic a vstup na pole mezinárodní, a to především do časopisů, které formují obor jako takový. V nich česká stopa dosud chybí nebo je velmi malá. V oblasti didaktiky biologie uvádí databáze RIV ve sledovaném období 8 článků v časopisech s IF a dalších 14 článků v databázi SCOPUS. V oblasti environmentální výchovy je to 6 článků v časopise s IF a 10 v databázi SCOPUS. V rámci didaktiky geologie nejsou v databázi RIV žádné články tohoto typu uvedeny.

Pro zvýšení počtu publikačních výstupů českých výzkumníků v oblasti didaktiky biologie a geologie v renomovaných časopisech indexovaných v databázích Web of Science (WOS) a SCOPUS je třeba zaměřit se do budoucna na aktuální výzkumná témata, která budou přinášet nové poznatky o efektivních metodách výuky biologie (srov. Singer et al., 2013; Dolan, 2015) a budou mít obecnou platnost a možnosti využití. $\mathrm{Z}$ přehledu několika výše uvedených tuzemských výzkumných studií je patrné, že se jedná mnohdy o deskriptivní studie s lokálním dopadem, které poměrně detailně popisují aktuální stav výuky vybraného biologického tématu v ČR (srov. Janštová \& Jáč, 2015 na př́lkladu molekulární biologie) nebo přináší komparaci daného výukového tématu v ČR se zahraničím (srov. Müllerová, 2015 na př́kladu evoluční biologie). Tyto studie sice mohou být cenné, protože z pohledu probíhajících revizí přírodopisného (biologického) kurikula se jeví jako klíčová kvalitně provedená ontodidaktická transformace obsahu biologie na úrovni RVP, ale také př́prava „modelového“ ŠVP, kde by byly učivo a očekávané výstupy detailněji rozpracovány. Současný hlavní proud výzkumu v didaktice biologie se však zaměřuje především na hledání způsobů, které prokazatelně povedou u žáků a studentů $\mathrm{k}$ lepšímu porozumění učivu a jejich aktivnímu zapojení do výuky (přehledně viz např. Freeman et al., 2014; Dolan, 2015). Především takto koncipované studie mají šanci projít náročným recenzním řízením v zahraničních oborově didaktických časopisech. Zároveň ale při srovnání se zahraničními studiemi najdeme některé podobnosti, např́klad pozornost upřenou na badatelsky orientovanou výuku (srov. Lin et al., 2014). V pracích zaměřených na didaktiku biologie jak u nás, tak ve světě, je značně zastoupený kvantitativní výzkumný design, počty respondentů jsou často poměrně nízké (Gül \& Sözbilir, 2016).

O pragmatičnosti výzkumníků v Česku i v zahraničí svědčí využití nejsnáze dostupných skupin respondentů, žáků druhého stupně základních škol a vysokoškolských studentů (srov. Gül \& Sözbilir, 2016). Výrazná převaha těchto skupin respondentů je zřejmě způsobena kombinací několika různě silných faktorů. Velká část výzkumníků pochází z pedagogických fakult, kde se tradičně připravují učitelé 2 . stupně základní školy, pedagogické fakulty mají poměrně rozsáhlou sít fakultních škol, s nimiž úzce spolupracují. Proto jsou tito žáci a př́padně jejich učitelé nejčastější skupinou respondentů realizovaných výzkumů. Vyšší zastoupení výzkumů realizovaných u studentů vysokých škol pak opět souzní s „dostupnosti““ respondentů z řad studentů jednotlivých výzkumníků. Výzkumy v mateřských školách a na prvním stupni pak naráží na specifické obtiže se sběrem dat, a to zejména u kvantitativně zaměřených výzkumů, které převládají.

Bez zajímavosti není fakt, že články věnované metodologii oborově didaktického výzkumu jsou v rámci celého období pouze dva, což je jeden z aspektů naznačujících mnohdy ne zcela vhodné metodologické uchopení některých realizovaných výzkumů. Hlubší analýza nejčastějších metodologických prohřešků přesahuje ambice tohoto textu. Zároveň se domníváme, že se jedná o vhodný námět pro navazující analýzu, jejíž výsledky by mohly přinést výzkumníkům $\mathrm{v}$ oblasti didaktiky biologie (a př́ibuzných disciplín) cenné poznatky pro zkvalitnění přípravy a realizace empirických studií. 
Na to, že didaktika biologie je zavedeným oborem, poukazuje nejen stoupající kvalita domácích oborově didaktických časopisů, ale také možnost realizovat doktorské studium ve dvou oborově didakticky zaměřených studijních programech. Kromě v úvodu zmiňovaného a již etablovaného Vzdělávání v biologii (PF JU \& PF UK) je to také studijní obor Didaktika primárního př́rodovědného vzdělávání (PF UJEP), jehož záběr je, jak naznačuje název, významně užší. Existence silných doktorských programů je jedním ze základních rozvojů většiny vědeckých oborů, didaktiky přírodních věd a environmentální výchovy nevyjímaje. Rozvoj odborné komunity také podporuje již zavedená konference Trendy v didaktice biologie. V souvislosti s ní se nabízí domněnka, že důvodem faktu, že v konferenčních letech $(2014,2016,2018)$ je tuzemských publikací zaměřených na didaktiku biologie a geologie méně, a naopak v letech po konání konference více, je zpracování prezentovaných výstupů v dalším roce do časopiseckého příspěvku.

\section{Závěr}

V období 2008-2018 bylo v didaktice biologie, geologie a environmentální výchovy publikováno 145 výzkumných a přehledových prací. Je patrné formování funkčních výzkumných týmů a objevují se noví odborníci zaštitující konkrétní témata. Výzkum v oblasti didaktiky geologie je ve srovnání se zbývajícími analyzovanými obory více roztříštěný a spiše solitérní.

Závěry výzkumů jsou prezentovány především v časopisech a monografiích, kde je vyšší jistota podrobného recenzního řízení.

Výsledky analýzy ukázaly, že uplynulá dekáda výzkumu v didaktice biologie přinesla poměrně malý podíl teoretických či empirických studií, které by obsahovaly nové poznatky či podněty ve vztahu k úpravám cílů a obsahu př́rodopisného (biologického) vzdělávání. Mnohé z nich opakovaně poukazují na nedostatky týkající se ontodidaktické transformace oborového biologického obsahu do školního kurikula (srov. Janštová \& Jáč, 2015; Müllerová, 2015; Dvořáková \& Absolonová, 2016, 2017; Hájková, 2017). Výzkum byl realizován zejména $\mathrm{v}$ oblastech biologie, které aktuálně prochází dynamickým vývojem (molekulární biologie, evoluční biologie), přibývá v nich velké množství nových vědeckých poznatků a mnohdy mají také značný společenský dopad (např. etické otázky spojené moderními metodami molekulární biologie či postavení člověka vůči zbytku organismů).

Teoretické a přehledové studie pak přináší nové podněty, mnohdy inspirované zahraničními přístupy, pro výuku př́rodopisu a biologie, jako je např. implementace badatelsky orientovaného vyučování (přehledně např. Papáček, 2010) nebo větší zastoupení terénní výuky (Činčera \& Holec, 2016). V návaznosti na Papáčka et al. (2015) konstatujeme, že pozitivní změny v didaktice biologie, geologie a environmentální výchovy v České republice pokračují. Množství výzkumů i jejich autorů roste a jsou, co do zaměření a provedení, mnohdy srovnatelné se zahraničními studiemi. Tento nastoupený trend snad zachovají absolventi a budoucí absolventi doktorských programů zaměřených na didaktiku biologie.

\section{Poděkování}

Děkujeme prof. RNDr. Miroslavu Papáčkovi, CSc., a RNDr. Ivě Kubištové, Ph.D., za kritické pročtení a zrecenzování první verze textu, ze kterého tento článek vychází. Zároveň děkujeme oběma anonymním recenzentům příspěvku, jejichž konstruktivní připomínky vedly ke zkvalitnění konečné verze textu. Př́spěvek vznikl v rámci př́pravy podkladové studie pro revize Rámcového vzdělávacího programu pro základní vzdělávání, autoři by proto chtěli poděkovat Národnímu ústavu pro vzdělávání za souhlas s publikováním upravené a rozššřené verze př́ispěvku v časopise Scientia in educatione.

Vènováno prof. RNDr. Miroslavu Papáčkovi, CSc.

\section{Literatura}

Činčera, J. (2013a). Střediska ekologické výchovy mezi teorii a praxí. BEZK, Agentura Koniklec a Masarykova univerzita.

Činčera, J. (2013b). Environmentální výchova: efektivní strategie. BEZK, Agentura Koniklec a Masarykova univerzita

Činčera, J., \& Holec, J. (2016). Terénní výuka ve formálním vzdělávání. Envigogika, 12(2), 1-19. https://doi.org/10.14712/18023061.533

Činčera, J., Jančaříková, K., Matějček, T., Lupač, M.. Šimonová, P., Bartoš, J., \& Broukalová, L. (2016). Environmentální výchova z pohledu učitelů. Masarykova univerzita.

Daniš, P. (2018). Tajemství školy za školou: Proč učení venku v př́rodě zlepšuje vzdělávací výsledky, motivaci a chováni žákư. Ministerstvo životního prostředí. 
Dirks, C. (2011). The current status and future direction of biology education research. National Research Council (Board on Science Education Commissioned Paper).

http://http://sites.nationalacademies.org/DBASSE/BOSE/DBASSE_071087

Dolan, E. L. (2015). Biology education research 2.0. CBE-Life Sciences Education, 14, (1-2).

Dvořáková, R. M., \& Absolonová, K. (2016). Obsahová analýza tématu evoluce člověka v českých učebnicích dějepisu. Scientia in educatione, 7(2), 34-37. https://doi.org/10.14712/18047106.358

Dvořáková, R. M., \& Absolonová, K. (2017). Obsahová analýza tématu evoluce člověka v českých učebnicích př́rodopisu a biologie. Scientia in educatione, 8(2), 34-37. https://doi.org/10.14712/18047106.765

Freeman, S., Eddy, S. L., McDonough, M., Smith, M. K., Okoroafor, N., Jordt, H., \& Wenderoth, M. P. (2014). Active learning increases student performance in science, engineering, and mathematics. Proceedings of the National Academy of Sciences of the United States of America, 111(23), 8410-8415. https://doi.org/10.1073/pnas.1319030111

Gilbert, J. K., De Jong, O., Justi, R., Treagust, D. F., \& Van Driel, J. H. (2003). Research and development for the future of chemical education. In J. K. Gilbert, O. De Jong, R. Justi, D. F. Treagust, \& J. H. Van Driel (Eds.), Chemical education: Towards research-based practice (pp. 391-408). Springer.

Gül, S., \& Sözbilir, M. (2015). Biology education research trends in Turkey. Eurasia Journal of Mathematics, Science \& Technology Education, 11(1), 93-109. https://doi.org/10.12973/eurasia.2015.1309a

Gül, Ş., \& Sözbilir, M. (2016). International trends in biology education research from 1997 to 2014: A content analysis of papers in selected journals. Eurasia Journal of Mathematics, Science and Technology Education, 12(6), 1631-1651. https://doi.org/10.12973/eurasia.2015.1363a

Hájková, J. (2017). Dějiny přírodních věd: Jejich místo ve škole a v učebnicích biologie. Scientia in educatione, 8(2), 39-51. https://doi.org/10.14712/18047106.758

Chang, Y.H., Chang, C. Y., \& Tseng, Y.-H. (2010). Trends of science education research: An automatic content analysis. Journal of Science Education and Technology, 19(4), 315-331. https://doi.org/10.1007/s10956-009-9202-2

Jančaříková, K. (2015). Didaktické přistupy k př́rodovědnému vzdělávání předškolních dětí a mladších žáků. Univerzita Karlova, Pedagogická fakulta.

Jančaříková, K., \& Havlová, J. (2014). Činnosti se zvíraty v předškolním vzdělávání. Raabe.

Janštová, V., \& Jáč, M. (2015). Výuka molekulární biologie na gymnáziích: analýza současného stavu a možnosti její podpory. Scientia in educatione, 6(1), 14-39. https://doi.org/10.14712/18047106.145

King, C. (2008). Geoscience education: An overview. Studies in Science Education, 44(2), 187-222. https://doi.org/10.1080/03057260802264289

King, C. (2015). The need for an international geoscience school syllabus: Its development and publication. Science Education International, 26(4), 420-438.

Lee, M.-H., Wu, Y.-T., \& Tsai, C.-C. (2009). Research trends in science education from 2003 to 2007: A content analysis of publications in selected journals. International Journal of Science Education, 31(15), 1999-2020. https://doi.org/10.1080/09500690802314876

Lewis, E. B., \& Baker, D. R. (2010). A call For a new geoscience education research agenda. Journal of Research in Science Teaching, 47(2), 121-129. https://doi.org/10.1002/tea.20320

Lin, T. C., Lin, T. J., \& Tsai, C. C. (2014). Research trends in science education from 2008 to 2012: A systematic content analysis of publications in selected journals. International Journal of Science Education, 36(8), 1346-1372. https://doi.org/10.1080/09500693.2013.864428

Lin, T. J., Lin, T. C., Potvin, P., \& Tsai, C. C. (2018). Research trends in science education from 2013 to 2017 : A systematic content analysis of publications in selected journals. International Journal of Science Education, 41(3), 367-387. https://doi.org/10.1080/09500693.2018.1550274

Moher, D., Liberati, A., Tetzlaff, J., Altman, D. G., \& The PRISMA Group (2009). Preferred reporting items for systematic reviews and meta-analyses: The PRISMA statement. PLOS Medicine, 6(7), e1000097. https://doi.org/10.1371/journal.pmed.1000097

Müllerová, L. (2015). Termín „evoluce“ a jeho vymezení a použití v českých a britských učebnicích přírodopisu a biologie. Scientia in educatione, 6(1), 40-79. https://doi.org/10.14712/18047106.120

Papáček, M. (2010). Badatelsky orientované př́rodovědné vyučování cesta pro biologické vzdělávání generací Y, $\mathrm{Z}$ a alfa? Scientia in educatione, 1(1), 33-49. https://doi.org/10.14712/18047106.4

Papáček, M. (2012). Současný výzkum v didaktice biologie v České republice: přehled. In V. Ježková (Ed.), Kvalita ve vzdèlávání. XX. Výročni konference České asociace pedagogického výzkumu. Sborník anotací (s. 120). Univerzita Karlova, Pedagogická fakulta. 
Papáček, M. (2016). Podporovaný výzkum v didaktice biologie v Ceské republice: dvanáct let poté... In L. Pavlasová (Ed.), Trendy v didaktice biologie. Sborník abstraktů (s. 10). Univerzita Karlova, Pedagogická fakulta.

Papáček, M., Čížková, V., Kubiatko, M., Petr, J., \& Závodská, R. (2015). Didaktika biologie: didaktika v rekonstrukci. In I. Stuchlíková, T. Janík, Z. Beneš, M. Bílek, K. Brücknerová, M. Černochová, V. Čížková, H. Ctrnáctová, L. Dvořák, K. Dytrtová, B. Gracová, O. Hník, M. Kekule, K. Kostková, M. Kubiatko, M. Nedělka, J. Novotná, M. Papáček, J. Petr, ... V. Žák, Oborové didaktiky: vývoj - stav - perspektivy (s. 225-257). Masarykova univerzita.

Pavlasová, L., Hrouda, L., Teodoridis, V., Andreska, J., Ř́íhová, D., Vančata, V., Novotný, P., Řezníček, J., \& Novotná, M. (2015). Př́rodovědné exkurze ve školní praxi. Univerzita Karlova, Pedagogická fakulta.

Petr, J. (2014). Možnosti využití úloh z Biologické olympiády ve výuce př́rodopisu a biologie. Inspirace pro badatelsky orientované vyučování. Jihočeská univerzita v Českých Budějovicích, Pedagogická fakulta.

Rokos, L., \& Holec, J. (Eds.) (2019). Podkladová studie $k$ revizi rámcových vzdělávacích programů $v$ oblasti vzděláváni o živé a neživé př́rodě. Jak budeme učit přírodopis, biologii a geologii v př́štích letech? Národní ústav pro vzdělávání.

Rusek, M., \& Vojír, K. (2018). Konference o projektovém vyučování: ohlédnutí za 15 ročníky. In M. Rusek \& K. Vojír (Eds.), Project-based education in science education (s. 35-43). Univerzita Karlova, Pedagogická fakulta.

Řezníčková, D., Cídlová, H., Čížková, V., Čtrnáctová, H., Cudová, R., Hanus, M., Kubiatko, M., Marada, M., Matějček, T., \& Trnová, E. (2013). Dovednosti žákư ve výuce biologie, geografie a chemie. P3K s. r. o.

Singer, S. R., Nilsen, N. R., \& Schweingruber, H. A. (2013). Biology education research: Lessons and future directions. CBE-Life Sciences Education, 12(Summer 2013), 129-132. https://doi.org/10.1187/cbe.13-03-0058

Stuchlíková, I., Janík, T. Beneš, Z., Bílek, M., Brücknerová, K., Černochová, M., Čížková, V., Čtrnáctová, H., Dvořák, L., Dytrtová, K., Gracová, B., Hník, O., Kekule, M., Kostková, K., Kubiatko, M., Nedělka, M., Novotná, N., Papáček, M., Petr, J., ...Žák, V. (2015). Oborové didaktiky: vývoj - stav - perspektivy. Masarykova univerzita.

Tsai, C., \& Wen, L. M. (2005). Research and trends in science education from 1998 to 2002: A content analysis of publication in selected journals. International Journal of Science Education, 27(1), 3-14.

https://doi.org/10.1080/0950069042000243727

Turanová, L., \& Ružek, I. (2015). Didaktika geológie na Slovensku - história, súčasný stav a perspektívy. Scientia in educatione, 6(1), 123-132. https://doi.org/10.14712/18047106.125

\section{Př́loha 1 - Analyzované publikace}

1. Andreska, J. (2008). Poznávání přírodnin jako didaktický problém. Biologie - chemie - zeměpis, $17(5), 229-232$.

2. Andreska, J., \& Mejzr, M. (2012). Velké šelmy pohledem žáků ZŠ. Envigogika, 8(1), 1-19.

3. Andreska, J., \& Švecová, K. (2015). Analýza aktuálních kompetencí žáků a studentů v určování našich obratlovců, Envigogika, 9(2), 1-24.

4. Bartoš, J., \& Matějček, T. (2015). Development of environmental attitudes from the perspective of teachers from the second level of primary schools. Envigogika, 10(2), 1-17.

5. Brestenská, B., Cibulková, J., \& Ivánková, P. (2017). The use of digital technologies in the science camp VEBOR. e-Pedagogium, 17(4), 104-118.

6. Beňková, V., \& Činčera, J. (2010). Prožitkové naučné stezky jako prostředek environmentální interpretace krajiny. Envigogika, 5(2), 1-19.

7. Bílek, M. (2008). Zájem žáků o přírodní vědy jako předmět výzkumných studií a problémy aplikace jejich výsledků v pedagogické praxi. Acta Didactica, 2, nestránkováno.

8. Bílek, M., Doulík, P., Šimonová, I., \& Škoda, J. (2016). Learning style as a factor influencing the effectiveness of the inquiry-based science education at lower secondary schools. Journal of Baltic Science Education, 15(5), 588-601.

9. Brabcová, B., Vodová, L., \& Hvězdová, K. (2018). Analýza tématu Řasy ve vybraných učebnicích př́rodopisu. Scientia in educatione, 9(1), 4-36.

10. Broukalová, L., Broukal, V., Činčera, J., \& Sopůšková, Z. (2015). "Two are more than one": Evaluation of a programme operated by the Bumblebee - Friends of Nature organization. Envigogika, $1(2), 1-30$.

11. Cídlová, H., Kubiatko, M., Bayerová, A., \& Petrů, M. (2012). Oblíbenost př́rodovědných předmětů mezi žáky Zঙ̌S. Biologie - chemie - zeměpis, 21(1), 4-7. 
12. Činčera, J. (2008). Evaluace programu Ekoškola. Envigogika, 3(2), 1-32.

13. Činčera, J. (2008). Evaluační strategie středisek ekologické výchovy. Envigogika, 3(2), 1-18.

14. Činčera, J. (2009). Analýza průřezového tématu Environmentální výchova v Rámcovém vzdělávacím programu pro základní vzdělávání. Envigogika, 4(1), 1-27.

15. Činčera, J. (2011). Rozvoj výzkumných kompetencí žáků na základní škole: zkušenosti z evaluace programu o Jizerských horách. Envigogika, 6(3), 1-13.

16. Činčera, J. (2011). Vliv pobytového programu o Jizerských horách na proenvironmentální postoje a hodnoty. Envigogika, 6(3), 1-16.

17. Činčera, J. (2012). Děti a les: analýza mentálních map žáků čtvrtých tříd. Envigogika, 7(1), 1-15.

18. Cinčera, J. (2012). Evaluace orientovaná na uživatele: zkušenost s pobytovým programem Člověk a prostředí. Orbis Scholae, 6(3), 119-134.

19. Činčera, J. (2012). Strach z lesa: vliv programu environmentální výchovy na snižování obav žáků z pobytu v lesním prostředí. Envigogika, 7(2), 1-15.

20. Cinčera, J. (2012). Vliv výukového programu na rozvíjení environmentální senzitivity žáků. Envigogika, $7(2), 1-15$.

21. Činčera, J. (2013). Evaluation of an educational exhibition on global issues and consumer responsibility: From involvement to hopelessness. Envigogika, 8(2), 1-13.

22. Činčera, J. (2013). Managing cognitive dissonance: Experience from an environmental education teachers training course in the Czech Republic. Journal of Teacher Education for Sustainability, $15(2), 42-51$.

23. Činčera, J. (2013). Paradigmatická proměna domácího pojetí environmentální výchovy. Pedagogika, 2013(2), 182-197.

24. Cinčera, J. (2013). Vliv pobytového programu na atraktivitu Jizerských hor. Envigogika, 8(1), 1-10.

25. Činčera, J. (2014). To think like a scientist: An experience from the Czech primary school inquirybased learning programme. The New Educational Review, 36(2), 118-130.

26. Cinčera, J. (2015). Application of the RWL model for evaluation of a residential environmental program. Envigogika, 10(3), 1-14.

27. Činčera, J. (2015). Real World Learning: A critical analysis. Envigogika, 10(3), 1-12.

28. Činčera, J., Broukal, V., Broukalová, L., Kroufek, R., Šimonová, P., \& Skalík, J. (2017). Eco-School in kindergartens: The effects, interpretation, and implementation of a pilot program. Environmental Education Research, 23(7), 919-936.

29. Cinčera, J., Fleková, A., \& Kopecký, J. (2011). „S TURem tu i zítra budem“: evaluace programu Ekocentra Podhoubí. Envigogika, 6(3), 1-17.

30. Činčera, J., Gilar, P., \& Sokolovičová, J. (2010). Specializační studium pro koordinátory environmentální výchovy, vzdělávání a osvěty: interpretace a efektivita z pohledu absolventů. Envigogika, 5(1), 1-20.

31. Činčera, J., \& Havlíček, F. (2016). Centra environmentálního vzdělávání z pohledu učitelů. Envigogika, 11(2), 1-14.

32. Činčera, J., \& Holec, J. (2016). Terénní výuka ve formálním vzdělávání. Envigogika, 12(2), 1-19.

33. Činčera, J., \& Johnson, B. (2013). Earthkeepers in the Czech Republic: Experience from the implementation process of an earth education programme. Envigogika, 8(4), 1-14.

34. Činčera, J., Johnson, B., \& Kovačiková, S. (2015). Evaluation of a place-based environmental education program: From there to here. Applied Environmental Education \& Communication, 14(3), $178-186$.

35. Činčera, J., Kohoutová, K., \& Sokolovičová, J. (2010). Učastníci specializačního studia pro koordinátory environmentální výchovy: očekávání, hodnocení a první př́ínosy. Envigogika, 5(3), 1-23.

36. Činčera, J., \& Komárková, M. (2010). Využití kresby jako prostředku evaluace programu na rozvíjení environmentální senzitivity mladších dětí. Envigogika, 5(2), 1-14.

37. Čnčera, J., Koróny, S., Smolaková, N., \& Švajda, J. (2016). The benefit of the GLOBE program for the development of inquiry competence in the Czech and Slovak contexts. International Journal of Environmental \& Science Education, 11(16), 9507-9519.

38. Činčera, J., \& Kováčiková, S. (2014). Being an eco-team member: Movers and fighters. Applied Environmental Education and Communication, 13(4), 227-233.

39. Cinčera, J., Kováčiková, S., Mašková, V., Medal, R., \& Medalová, K. (2012). The Green School: An impact of evaluation on decision-making about a program. The New Educational Review, 30(4), $17-29$.

40. Činčera, J., \& Krajhanzl, J. (2013). Eco-Schools: What factors influence pupils? Action competence for pro-environmental behavior. Journal of Cleaner Production, 61(25), 117-121.

41. Činčera, J., Kulich, J., \& Gollová, D. (2009). Efektivita, evaluace a podpora programů environmentální výchovy. Envigogika, 4(2), 1-31. 
42. Činčera, J., \& Macháčková, P. (2009). Evaluace pobytového programu Podblanického ekocentra. Envigogika, 4(3), 1-17.

43. Činčera, J., \& Mašková, V. (2011). GLOBE in the Czech Republic: A program evaluation. Environmental Education Research, 17(4), 499-517.

44. Činčera, J., Medek, M., Činčera, P., Lupač, M., \& Tichá, I. (2017). What science is about - development of the scientific understanding of secondary school students. Research in Science and Technological Education, 35(2), 183-194.

45. Činčera, J., Stejskal, J., Mach, M., \& Lupač, M. (2014). "Organic food is fertilised at night": Why people (do not) buy environmentally friendly products. Envigogika, 9(1), 1-21.

46. Cinčera, J., \& Simonová, P. (2017). "I am not a big man": Evaluation of the issue investigation program. Applied Environmental Education and Communication, 16(2), 84-92.

47. Činčera, J., Winklerová, K., Křepelková, Š., \& Kroufek, R. (2018). The GLOBE Program: Longterm memories of program-relevant experience. The Journal of Environmental Education, 49(5), 400-410.

48. Č́žžková, V., \& Lustigová, V. (2009). Analýza úloh v učebnicích biologie pro základní školy a gymnázia. Biologie - chemie - zeměpis, 18(2), 78-83.

49. Cudová, R., Kubiatko, M., Radvanová, S., \& Č́žková, V. (2013). The teachers' opinions and requirements of biology skills. Journal of Baltic Science Education, 12(5), 579-591.

50. Daniš, P. (2013). Nové vymezení environmentální gramotnosti a návrh na její mezinárodní hodnocení v PISA 2015. Envigogika, 8(3), 1-16.

51. Doskočilová, Š., \& Mergl, M. (2012). Který druh reprezentuje typického hlavonožce? Arnica, 2(1-2), 10-18.

52. Dostál, P. (2010). Didaktika biologie - vývoj a současnost. Scientia in educatione, 1(1), 125-132.

53. Dvořáčková, S., \& Ryplová, R. (2012). Sonda do environmentální gramotnosti studentů př́rodovědně a ekologicky zaměřených oborů na Pedagogické fakultě JU. Envigogika, r(3), 1-22.

54. Dvořáková, R. M., \& Absolonová, K. (2016). Obsahová analýza tématu evoluce člověka v českých učebnicích dějepisu. Scientia in educatione, $7(2), 34-37$.

55. Dvořáková, R. M., \& Absolonová, K. (2017). Obsahová analýza tématu evoluce člověka v českých učebnicích přírodopisu a biologie. Scientia in educatione, 8(2), 34-37.

56. Fančovičová, J., \& Kubiatko, M. (2015). Záujem žiakov nižšieho sekundárneho vzdelávania o biologické vedy. Scientia in educatione, 6(1), 2-13.

57. Florianová, A. (2015). Rostlinné invaze v povědomí studentů vybraných gymnázií. Scientia in educatione, 6(2), 74-103.

58. Frainšič, M., Turčová, I., \& Martin, A. J. (2016). Czech Youth Summer Camps: More than playing games in nature. Envigogika, 11(2), 1-13.

59. Franěk, M. (2012). Nature Relatedness Scale. Český překlad škály měřící spojení s př́rodou. Envigogika, 7(1), 1-10.

60. Hájková, J. (2017). Dějiny přírodních věd: Jejich místo ve škole a v učebnicích biologie. Scientia in educatione, 8(2), 39-51.

61. Haláková, Z., \& Kubiatko, M. (2008). Sú buduci učitelia přírodovědných predmetov tvoriví? Pedagogika, 2008(1), 50-60.

62. Havlíčková, V., Bílek, M., \& Šorgo, A. (2018). Can virtual dissection replace traditional handson dissection in school biology laboratory work? Eurasia Journal of Mathematics, Science and Technology Education, 14(4), 1415-1429.

63. Havlíčková, V., Bílek, M., \& Šrgo, A. (2018). Virtuální pitvy a jejich akceptace studenty učitelství biologie v České republice. Scientia in educatione, 9(1), 37-47.

64. Heinz, J., Enghag, M., Stuchlíková, I., Cakmakci, G., Peleg, R., \& Baram-Tsabari, A. (2016). Impact of initiatives to implement science inquiry: A comparative study of the Turkish, Israeli, Swedish and Czech science education systems. Cultural Studies of Science Education, 12(3), 677-708.

65. Hlaváčová, L. (2015). Výuka evoluční biologie na základních a středních školách. Scientia in educatione, 6(2), 104-120.

66. Hlaváčová, L. (2016). Výuka evoluce a přírodního výběru na českých a britských školách. e-Pedagogium, 16(3), 127-138.

67. Hrabí, L. (2010). The text difficulty in some Czech natural science textbooks. The New Educational Review, 22(3-4), 143-148.

68. Hrabí, L. (2012). Natural science textbooks for the fourth grade and their text difficulty. Envigogika, $7(2), 1-7$.

69. Hrabí, L., Vránová, O., Machar, I., \& Pechanec, V. (2014). Text difficulty in Czech natural science textbooks for the fourth grade. The New Educational Review, 35(1), 29-40. 
70. Hrabí, L., Vránová, O., \& Müllerová, M. (2010). Kvalita současných učebnic př́rodopisu z různých pohledů. e-Pedagogium, 10(4), 9-18.

71. Hromádka, Z. (2008). Vztahy mezi vědomostmi, postoji a skutečným jednáním u žáků druhého stupně základní školy v rámci environmentální výchovy. Pedagogická orientace, 18(1), 22-33.

72. Chytrý, V., \& Kroufek, R. (2017). Možnosti využití Likertovy škály - základní principy aplikace v pedagogickém výzkumu a demonstrace na příkladu zjištování vztahu člověka k přírodě. Scientia in educatione, $8(1), 2-17$.

73. Janáková, M. (2016). Permakultura a teorie environmentální výchovy (EV): mapující přehledová studie. Envigogika, 11(2), 1-31.

74. Jančaříková, K. (2009). Př́rodovědná inteligence: diagnostika a péče o přírodovědně talentované žáky a studenty v ČR. Envigogika, 4(3), 1-11.

75. Jančaříková, K., \& Pavlasová, L. (2018). Dovednost studentů učitelství biologie aplikovat teorii didaktických situací při přípravě na výuku. Scientia in educatione, 9(1), 48-65.

76. Janštová, V., Jáč, M., \& Dvořáková, R. (2015). Faktory motivující žáky středních škol k zájmu o obor biologie a účasti v předmětových soutěžích s biologickou tematikou. e-Pedagogium, 15(1), $56-71$.

77. Janštová, V., \& Jáč, M. (2015). Výuka molekulární biologie na gymnáziích: analýza současného stavu a možnosti její podpory. Scientia in educatione, 6(1), 4-39.

78. Janštová, V., \& Novotný, P. (2017). Pedagogický výzkum jako součást kvalifikačních prací studentů učitelství biologie. Scientia in educatione, 8(2), 52-69.

79. Jelemenská, K. (2009). Prepojenost’ výberu učebných obsahov, zistovania výkonov žiakov a predstáv učitelov. Význam empirických výsledkov výskumu didaktiky biológie na príkladu vyučovania evolúcie. Pedagogika, 2009(2), 164-181.

80. Jirásek, I., Veselský, P., \& Poslt, J. (2017). Winter outdoor trekking: Spiritual aspects of environmental education. Environmental Education Research, 23(1), 1-22.

81. Johnson, B., \& Činčera, J. (2015). Examining the relationship between environmental attitudes and behaviour in education programmes. Sociálni studia, 12(3), 97-111.

82. Kapitulčinová, D. (2017). Kalkulačky environmentálních stop jídla ve vzdělávání a představení Nutriční stopy jako nástroje pro podporu udržitelné spotřeby potravin. Envigogika, 12(2), 1-25.

83. Kaufnerová, V., \& Vágnerová, P. (2013). Sinice a řasy v učebnicích pro základní a střední školy. Arnica, 3(1-2), 9-18.

84. Kekule, M., Žák, V., Ješková, Z., \& Kimáková, K. (2017). Gender diferences when assessing impact of the inquiry based science education. The New Educational Review, 48(2), 100-114.

85. Kroufek, R., Chytrý, V., \& Uhrinová, M. (2018). The effect of the type of the finished high school on the nature relatedness of pre-service primary teachers. The New Educational Review, 54(4), $231-243$.

86. Kubiatko, M. (2011). Bez prírodopisu to nejde alebo ako ho vnímajú žiaci základných škôl. Studia Paedagogica, 16(2), 75-88.

87. Kubiatko, M. (2012). Kindergarten childrens perception of animals focusing on the look and fear of animals. Educational Sciences: Theory \& Practice, 12(4), 3181-3186.

88. Kubiatko, M. (2012). The investigation of Czech lower secondary school pupils toward science subjects. Journal of Educational and Social Research, 2(8), 11-17.

89. Kubiatko, M. (2014). The environmental literacy of lower secondary school pupils, high school and college students. Journal of Environmental Science and Engineering Technology, 2(1), 2-8.

90. Kubiatko, M. (2017). Predstavy žiakov o vylučovacej a endokrinnej sústave. Scientia in educatione, $8(2), 70-83$.

91. Kubiatko, M., \& Balátová, K. (2014). Are storks homosexuals? Persistence of misconceptions among university students. Journal of Baltic Science Education, 13(4), 448-457.

92. Kubiatko, M., \& Vašíčková, M. (2011). Do we need biological skills for our future life? The elementary school pupils views on the importance of biological skills. Western Anatolia Journal of Educational Sciences, 2, 153-160.

93. Kubiatko, M., \& Vašíčková, M. (2013). Ověřování výzkumného nástroje zaměřeného na zkoumání názorů žáků na důležitost biologických dovedností. e-Pedagogium, 13(1), 69-81.

94. Kubiatko, M., \& Vlčková, J. (2011). Návrh výzkumného nástroje na zkoumání postojů žáků 2. stupně ZŠ k př́rodopisu. Scientia in educatione, 2(1), 49-67.

95. Kubrická, J., \& Hromádka, Z. (2015). Environmental elements in an English language textbook. Envigogika, 10(4), 1-9.

96. Machar, I., Činčera, J., Vránová, O., Pechanec, V., Kiliánová, H., \& Málková, J. (2014). Innovation in biology and educational didactics in pre gredual training of secondary biology teachers in the context of current changes in educational system. The New Educational Review, 37(3), 31-42. 
97. Malcová, K., \& Janštová, V. (2018). Jak jsou hodnoceny jednotlivé obory biologie žáky 2. stupně ZS̆ a nižšśho stupně gymnázia? Biologie - chemie - zeměpis, 27(1), 23-34.

98. Matějček, T., \& Bartoš, J. (2012). Environmentální gramotnost učitelů a studentů učitelství. Envigogika, $7(2), 1-14$.

99. Müllerová, L. (2012). Pojem evoluce a jeho vnímání žáky základních a středních škol. Scientia in educatione, 3(2), 33-64.

100. Müllerová, L. (2015). Termín „evoluce“ a jeho vymezení a použití v českých a britských učebnicích př́rodopisu a biologie. Scientia in educatione, 6(1), 40-79.

101. Němečková, L., \& Pavlasová, L. (2016). Efektivita vybraných metod a forem výuky tématu morfologie listů. Biologie - chemie - zeměpis, 25(2), 69-71.

102. Papežová, N. (2018). Evaluace tř́ výukových programů s tématikou permakultury. Envigogika, 13(2), 1-13.

103. Pavlasová, L. (2015). Disertační práce se zaměřením na didaktiku biologie v České republice v letech 2004-2013. Scientia in educatione, 6(2), 4-15.

104. Pavlasová, L. (2017). Profesní vidění studentů učitelství biologie zaměřené na obor a oborově didaktické jevy. Scientia in educatione, 8(2), 84-99.

105. Pavlátová, V., \& Kroufek, R. (2018). Pohled učitelů na obtížnost vybraných environmentálních fenoménů v učebnicích pro základní školy. Scientia in educatione, 9(2), 57-79.

106. Petiška, E. (2018). Využívání otevřených vzdělávacích zdrojů studenty environmentálních oborů v České republice. Envigogika, 13(1), 1-18.

107. Petr, J. (2010). Srovnání výběru př́rodnin v přírodovědném učivu na 1 . stupni ZŠS v různých vzdělávacích systémech. e-Pedagogium, 10(3), 89-103.

108. Petr, J. (2014). Living things in the science education at trimary school. The video research on the current state of instruction. The New Educational Review, 36(2), 131-143.

109. Petr, J., Budková, L., \& Kováříková, M. (2010). Znalosti vybraných př́írodnin u žáků prvního stupně ZŠ. e-Pedagogium, 10(4), 64-72.

110. Podroužek, L. (2011). Komparativní analýza vývoje učiva o horninách, nerostech a půdě v naší primární škole. Arnica, 1(2), 39-48.

111. Podroužek, L. (2011). Problematika vymezování a koncipování učiva přírodopisu v kurikulárních dokumentech základní školy z vývojového hlediska. Arnica, 1(1), 7-14.

112. Polášková, A. (2013). Lectures on ecology and environmental protection - previous knowledge and present attitudes of first year university students. Envigogika, 8(2), 1-18.

113. Pouchová, M. (2010). Školní projekty ve výuce př́rodovědných předmětů. Envigogika, 5(1), 1-20.

114. Pouchová, M. (2010). Školní projekty ve výuce př́írodovědných předmětů na 2 . stupni základních škol - česko-slovenský srovnávací výzkum. Scientia in educatione, 1(1), 101-117.

115. Pražáková, M., \& Pavlasová, L. (2017). Non-formal children and youth education focused on geoscience content in the Czech Republic. Pedagogická orientace, 27(4), 599-619.

116. Prokop, P., \& Kubiatko, M. (2014). Perceived vulnerability to disease predicts environmental attitudes. Eurasia Journal of Mathematics, Science and Technology Education, 10(1), 3-11.

117. Radvanová, S., Čížková, V., \& Martinková, P. (2018). Mění se pohled učitelů na badatelsky orientovanou výuku? Scientia in educatione, 9(1), 81-103.

118. Rokos, L., \& Vácha, Z. (2017). Integrated science and biology education as viewed by Czech university students and their attitude to inquiry-based scientific education. The New Educational Review, $47(1), 241-252$.

119. Rokos, L., \& Vomáčková, V.(2017). Hodnocení efektivity badatelsky orientovaného vyučování v laboratorních pracích při výuce fyziologie člověka na základní škole a nižším stupni gymnázia. Scientia in educatione, 8(1), 32-45.

120. Rokos, L., \& Závodská, R. (2015). Formative assessment and other assessment methods in biology education and pre-service biology teacher training in the Czech Republic. International Journal of Assessment and Evaluation, 23(2), 17-27.

121. Rokos, L., Závodská, R., Bílá, M., \& Řeháčková, L. (2013). The respondent - secondary school and university student and the primary biological education. Journal of International Scientific Publications: Educational Alternatives, Education, Research and Development, 11(1), 334-344.

122. Rokos, L., Závodská, R., Petr, P., \& Papáček, M. (2016). Formative assessment methods in biology education: Pedagogical study at primary school in the Czech Republic. Bulletin of the South Ural State University. Series Education, Educational sciences, 8(4), 94-99.

123. Ryplová, R., \& Řeháková, J. (2011). The benefit of research-oriented instruction for environmental education: Case study implementation for primary school education. Envigogika, 6(3), 1-10.

124. Schmutzerová, L., \& Bílek, M. (2010). Jak hodnotili čeští parnáctiletí žáci základních škol a studenti víceletých gymnázií environmentální problémy. Envigogika, 5(2), 1-12. 
125. Skalík (2015). Climate change awareness and attitudes among adolescents in the Czech Republic. Envigogika, 10(4), 1-19.

126. Strnadová, D., Brůhová Foltýnová, H., \& Jordová, R. (2017). Environmentální výchova hrou výsledky dopravní kampaně pro děti „Oblékáme hada Edu“. Envigogika, 12(1), 1-17.

127. Svobodová, S. (2017). Vliv vybraných proměnných na environmentální gramotnost žáků 2. stupně základní školy. Envigogika, 12(1), 1-22.

128. Svobodová, S. (2018). Konativní dimenze environmentální gramotnosti českých a slovenských žáků 2. stupně ZS̆. Envigogika, 13(2), 1-12.

129. Svobodová, S., \& Kroufek, R. (2016). Environmentální gramotnost žáků 2. stupně v Žatci - výzkumná sonda. Envigogika, 11(2), 1-17.

130. Svobodová, S., \& Kroufek, R. (2018). Možnosti využití škály MSELS pro testování environmentální gramotnosti na základních školách v České republice. Scientia in educatione, 9(2), 80-101.

131. Škoda, J., Doulík, P., Bílek, M., \& Šimonová, I. (2015). The effectiveness of inquiry based science education in relation to the learners' motivation types. Journal of Baltic science education, 14(6), 791-803.

132. Šorgo, A., Lamanauskas, V., Šašic, S., Šimic, E., Zehra, N., Tomažič, I., Kubiatko, M., Prokop, P., Ersozlu, A., Frančovičova, J., Bílek, M., \& Usak, M. (2017). Cross-national study on relations between motivation for science courses, pedagogy courses and general self-efficacy. Eurasia Journal of Mathematics, Science and Technology Education, 13(10), 6497-6508.

133. Šorgo, A., Usak, M., Kubiatko, M., Fančovičova, J., Prokop, P., Puhek, M., Škoda, J., \& Bahar, M. (2014). A cross-cultural study on freshmens knowledge of genetics, evolution, and the nature of science. Journal of Baltic Science Education, 13(1), 6-18.

134. Torkar, G., Kubiatko, M., \& Bajd, B. (2012). Assessing pre-service teachers (dis)liking of some animal species. Journal of Baltic science education, 11(4), 393-402.

135. Vacínová, M., \& Matějček, T. (2013). Intergenerational differences in personal relationship to nature. Envigogika, 8(2), 1-19.

136. Vačkář, D., \& Krkoška Lorencová, E. (2017). Aplikace participativní metody World Café v oblasti globálních problémů životního prostředí. Envigogika, 12(2), 1-25.

137. Vácha, Z. (2015). Didaktické využití školních zahrad v České republice na primárním stupni základních škol. Scientia in educatione, 6(1), 80-90.

138. Vácha, Z., \& Ditrich, T. (2016). Efektivita badatelsky orientovaného vyučování na primárním stupni základních škol v přírodovědném vzdělávání v Ceské republice s využitím prostředí školních zahrad. Scientia in educatione, $7(1), 6579$.

139. van den Berg, E. (2013). Didaktická znalost obsahu v laboratorní výuce: Od práce s přístroji k práci s myšlenkami. Scientia in educatione, 4(2), 74-92.

140. Vlčková, J. (2017). Miskoncepce v genetice: přehledová studie. e-Pedagogium, 17(3), 149-161.

141. Vlčková, J., \& Kubiatko, M. (2014). Př́rodopis v očích žáků 2. stupně základních škol. e-Pedagogium, 14(1), 20-37.

142. Vránová (2009). Tasks in natural science textbooks. e-Pedagogium, 9(1), 91-96.

143. Vránová (2012). Difficult learning tasks in biology curriculum. The New Educational Review, 30(4), 30-44.

144. Yilmaz, Z., Kubiatko, M., \& Topal, H. (2012). Czech childrens drawing of nature. Educational Sciences: Theory \& Practice, 12(4), 3111-3119.

145. Zahradník, M., \& Pachmanová, L. (2009). Příklad využití wiki-prostředí v environmentálním vzdělávání na vysoké škole: hodnocení kurzu Organizace a řízení ochrany životního prostředí. Envigogika, 4(3), 1-17. 